\title{
Women's Rights in the Islamic Family Law of Indonesia
}

\author{
Khoiruddin Nasution
}

Tulisan berikut membahas empat aspek tentang status dan hak-hak kaum wanita dalam perundang-undangan atau legislasi hukum di Indonesia. Empat aspek dimaksud adalah (1) hak dan kebebasan wanita untuk memilih calon pasangan, (2) peran dan kedudukan wali, (3) aturan tentang batas umur minmal untuk boleh melakukan pemikahan, dan (4) aturan pencatatan perkawinan dan aturan proses perceraian serta akibat hukumnya. Penulis antikel ini berpendirian bahwa secara umum status dan hakhak kaum wanita lebih terjamin dalam peraturan perunbdang-undangan hukum positif dari pada konsep konvensional dalam kitab-kitab fiqh.

Kata kunci: woman, Indonesia, rights, family law

n classical Islamic family law, ${ }^{1}$ which was formulated by most Muslim jurists (mujtahids/fugahâ'), developed the concept of the superiority of a man over a woman. As a result, the status of a Muslim woman became marginalized, and their rights of course are less guarantee.

In contrast to the classical Islamic family law, the contemporary Islamic family law, assigns woman in a better position. In some cases a woman's position even seems to be equal to the position of a man..$^{2}$ This is the case of the Family Law in Indonesia. According to Tahir Mahmood, in the family law of Indonesia, there are thirteen problems are developed from the classical concept to the contemporary one. Some of which are the role of marriage-guardian and the freedom of a woman to choose her spouse, registration of the marriage, polygamy, unilateral divorce rights of both parties, the minimum marriageage for a man and a woman, the right and responsibility of the spouses in their family life, inheritance, post divorce assistance for both parties, period of waiting and its implication, parent's rights relating to custody and guardianship of their children. ${ }^{3}$

Realizing the fact that family law covers many aspects, this research will only concentrate on certain aspects: the role of

1 Some writers call it Personal Law, see for example, Tahir Mahmood, in his book Personal Law in Islamic Countries (1987); R. Faridi and M. Siddiqi, (eds.), Muslim Personal Law (Delhi: Markazi Maktaba Islami, 1973). Therefore, both deal with a similar subject, Islamic law organizes family life.

2 J. N. D. Anderson, Hukum Islam di Dunia Moderen, terj. Machnun Husein (Surabaya: Amarpress, 1990). pp. 54-55; Norman Anderson, Law Reform in the Muslim World (London: The Athlone Press, 1976), pp. 100-146; John L. Esposito, Women in Muslim Family Law (Syracuse: Syracuse University Press, 1982), pp. 94-120; J. N. D. Anderson, "The Problem of Divorce in the Shari'a Law of Islam: Measures of Reform in Modern Egypt", Royal Central Asian Society, No. 37 (1950), pp. 169185; Idem. "Recent Developments in Shari" a Law", The Muslim World, 41 (1951), pp. 113- 
the marriage-guardian and the freedom of a woman to choose her partner, the minimum age of marriage, the registration of marriage, and the process and the effect of divorce. The paper therefore is a result of a research concerning the status and the rights of women in Indonesian Islamic Family Law.

Therefore, unlike Elizabeth W. White, who used nine indicators in analyzing the status of women in Muslim countries, ${ }^{4}$ the indicators used in this paper are only four, but it enable us nonetheless to observe the current status of Indonesian women, and simultaneously see the rights of them. The indicators are the freedom of choice of the candidate, minimum age of marriage, divorce, and registration of marriage.

The study concentrates on Indonesian Muslim family law, which according to Mahmood, is applied in a country where Islam neither forms part of its name, nor is formally declared as the state religion. ${ }^{5}$ To compare to other Muslim countries it is also provided a few of other Islamic Family Laws in similar case. The paper tries to prove the thesis that, theoretically, the status of women has increased, and at the same time the rights of them are more guarantee in the new law of personal status (Muslim family law) than it is in the classical concept, as formulated by classical Muslim jurists (mujtahids / fuqahâ).

The paper will be divided into four sections. After an introduction, the paper willbe followed by a survey of the main issue of the status of women and their rights in Indonesian family law to the case of the freedom of choice and the minimum age of the candidate, registration of marriage, and divorce. When it is discussed the freedom of choice of the candidate and her minimum age, it is also discussed the role of marriage guardian (wali nikah). The sub chapter therefore will be the guardian's consent, free- dom of choice and the age of the candidate. Conclusion will summarize the points made in the body of this study.

\section{The Guardian's Consent, Freedom of Choice and the Age of the Candidate}

With respect to the guardian's consent, according to Indonesian regulations, the

126, 186-198 and 271-288; Fazlur Rahman, "A Survey of Modernization of Muslim Family Law", Intemational Journal of Middle East Studies, 11 (1980), pp.. 452-453.

${ }^{3}$ Tahir Mahmood, Personal Law in Islamic Countries (New Delhi: Times Press, 1987), pp. 11-12.

${ }^{4}$ The indicators used by White to compare among 21 countries, are as follows: (i) Minimum Marriage Age, (ii) Marriage Registration, (iii) Dissolution of Marriage, (iv) Inheritance Reform, (v) Polygamy Pegulation, (vi) Abolition of Talaq (unilateral divorce), (vii) Abolition of Polygamy, (viii) Secular Inheritance law, and (ix) Civil Code Replacing All Religious Law. White, "Legal Reform as an Indicator of Women's Status," p. 60. To quote, "The following indicators are used to create a scale of relative improvement in women's status in Muslim countries: the establishment of a minimum legal age for marriage, the establishment of a registration requirement for marriage, the provision for women to request dissolution of marriage, reform in inheritance laws, regulation of polygamy, abolition of men's right of unilateral divorce, abolition of polygamy, establishment of secular inheritance law to replace religious inheritance law, and secularization of all personal law through establishment of a civil code that is not based upon religion." White, "Legal Reform as an Indicator of Women's Status," p. 53-54

${ }^{5}$ According to Mahmood, there are three categories of countries where the majority of population are Muslim, namely: (1) countries where "Islam" or "Islamic" is part of the official name, (2) countries which recognize Islam as the "state religion," and (3) countries neither of these descriptions apply. Tahir Mahmood, Statutes of Personal Law in Islamic Countries: History, Texts and Analysis, Revised Edition (Delhi: ALR, 1995), p. 1. 
mere fact of having a guardian is one of the essential requirements of marriage, for without him the marriage is invalid. ${ }^{6}$

In addition, in Indonesian regulations, it is expected that the guardian should of the same descent (wali nasab) only. But in special cases the position of wali nasabcan be replaced by an authorized guardian (wali hakim), namely: (a) if there is no wali nasab; (ii) if it is not possible for the wali nasab to be present; (iii) if there is no address for the wali nasab; (iv) if the wali nasab refuses to perform the duty expected of him. In the latter case especially, the position of wali nasab is assumed by the wali hakim with previous permission of the Islamic court. ${ }^{7}$

With respect to the freedom of the candidate to choose, the consent of each is needed in ratifying contract of marriage. The contract of marriage cannot be allowed to proceed if there is any doubt as to whether the candidates agree to the marriage. ${ }^{8}$ Agreement by the candidate can be made orally, or in writing, by a sign, or by silence implying no disagreement. ${ }^{9}$

In order to avoid any misunderstanding regarding the agreement, the candidate is questioned prior to signing the contract of marriage. ${ }^{10}$

In contrast, according to classical theory, a marriage-guardian has a special right (haq ijbar / enforcement right) through which a marriage-guardian can force his daughter to marry a certain man, while a man is free to choose his spouse. Contrary to the classical theory, based on above explanation, a marriage contract nowadays is only possible based on the free choice of both spouses, and a marriage-guardian has no right to force his daughter into marriage. In short, Indonesian Islamic Family Law does not recognize the existence of the enforcement marriage.
With respect to the minimum age for marriage, in Indonesian law this is set at nineteen years for a man and sixteen years for a woman. ${ }^{11}$ In addition, those who have not yet attained twenty-one years of age

${ }^{6}$ To quote compilation, art. 14, "to perform a marriage contract the following are necessary: (a) a candidate husband, (b) a candidate wife, (c) a guardian, (d) two witnesses, and (e) the marriage contract. Art. 19 of the compilation states, "the guardian of marriage is one of the requirements (rukun) that has to be fulfilled."

7 To quote Compilation, art, 23, “(1), wali hakim can perform the duties of wali nasab in case (i) if there is no wali nasab, or (ii) if it is not possible for the wali nasab to be present, or (iii) if there is no address for a wali nasab, or (iv) if a wali nasab refutes to do his position." Art. 23 , "(2) In the case of refuting to the position, the position of wali nasab can certainly be by wall hakim with previous permission of the Islamic court."

B To quote Law No. 1 of 1974, art. 6 (1) and Compilation, art. 16 (1), "A contract of marriage has to be at the previous agreement of the candidates." Art. 17 (2) of Compilation, "A contract marriage is not able to perform if the candidate disagree with the marriage."

${ }^{9}$ As stated in the Compilation, art. 16 (2) "An agreement from the female (wife candidate) can be communicated by gesture, word, sign or absence of disagreement."

10 Jo quote the Compilation, art. 17 (1), "Before performing the contract of marriage, the officer of registration will ask first of all if there is agreement or disagreement of the candidates in the front of two witnesses." Art. 17 (2), "In the case that either candidate disagrees with the agreement, the contract marriage will not be performed."

${ }^{11}$ As stated in art. 7 (1) of the law of 1974, "Marriage is permitted only if a man is nineteen years old and a woman is sixteen years old." 
must have permission from their parent. ${ }^{12}$ The law provides, however, in cases where this permission is not forthcoming, for a judge to override this rule. ${ }^{13}$

Before proceeding to a comparative study of how these regulations resemble these followed in other countries, it is important to note that the first Muslim ruler make regulation of minimum age of marriage was Emperor Akbar in India (1556-1605), who established these as sixteen for male and fourteen for female. ${ }^{14}$

To compare to other muslim countries of the existence of the marriage guardian and the freedom of choice of the candidate, it is important to cite some of the laws. First of all, Iraqi law allows for the nullification and punishment of forced marriage. ${ }^{15}$

Regarding the consent of a guardian, in Jordanian law, a difference is made between a virgin and a previously married woman (tayyibah). For a previously married woman more than eighteen years of age a guardian is not needed..$^{16}$ For a virgin woman who is eighteen years old, is married on her own dening that she has no guardian and marries herself, and it is later discovered she dose have a guardian shall be examined. If the spouses have equal status the marriage is considered to be binding. If not equal, the guardian can apply to the judge for dissolution of the marriage. ${ }^{17}$

In addition, a judge may give a woman in marriage at fifteen years of age, where

${ }^{12}$ As stated in art. 6 (2), of the law of 1974, "Marriage of spouses below twenty-one years old is compulsory to have permission from parent."

${ }^{13}$ To quote art. 7 (2), of the law of 1974 , "Marriage which is not in accordance with art. 7 (1) of the law of 1974, is still possible with the permission of the judge or another official." her guardian opposes the marriage without lawful justification. ${ }^{18}$

${ }^{14}$ White, "Legal Reform as an Indicator of Women's Status, p. 54.

${ }^{15}$ Mahmood, Personal Law, p. 18. To quote art. 9 of Jraq Law, "(1) No relative or third party may compel any person, male or female, to marry without his or her consent. A consent of marriage concluded by coercion shall be deemed void if consummation does not take place. Likewise no relative or third party may prevent a person who has the legal capacity to marry in accordance the provisions of this law from being married." "(2) Any person who contravenes the provisions of paragraph 1 of this Article shall be punished by detention for a period not exceeding three years and by a fine, or by one of these penalties, if he is a relative in the first degree. If, however, the person contravening this is not such a relative the penalty shall be imprisonment for a period not exceeding ten years, or detention for a period not exceeding three years." Dawoud El Alami dan Doreen Hinchcliffe, Islamic Marriage and Divorce Laws of the Arab World (London, the Hague, Boston: Kluwer Law International, 1996), p. 67-68; Mahmood, Personal, p. 118.

${ }^{16}$ This is stated in art. 13 of the law, "The consent of guardian shall not be required for the marriage of a woman who has previously married (tayyibah), who is of sound mind and who is more than eighteen years of age." AJ Alami and Hinchcliffe, Islamic Marriage and Divorce Laws, p. 82.

${ }^{17}$ As state in art. 22 of the law stated, "If a virgin or a woman who has been previously married and who has reached eighteen of age denies that she has a guardian and marries herself and it is later discovered that she has a guardian then the case shall be examined and if she has married a man of equal status the contract shall be binding even if the dower is less than the proper dower. If she has married a man who is not of equal status then the guardian shall be entitled to apply to the judge requesting dissolution of the marriage." Al Alami and Hinchcliffe, Islamic Marriage and Divorce Laws, p. 85.

${ }^{18}$ Art. 6 of the law states, "(1) A judge may, upon request, give in marriage a virgin who has reached fifteen years of age to a man who 
In Moroccan law the possibility of compulsion (ijbar) on the part of the guardian is entertained if it is feared that the woman will fall into immorality. ${ }^{19}$

As concerns to the age marriage, Iraqi law puts at eighteen years the minimum age of marriage establishing, no difference between man and woman. ${ }^{20}$ Those as young as fifteen years of age are also allowed to marry with the permission of the judge. ${ }^{21}$

Jordanian law states that the minimum age of marriage is sixteen years old for a man and fifteen years for woman. ${ }^{22}$ Interestingly, Jordanian law forbids too great a disparity in age between the parties, that the prospective husband can be no more than twenty years older than a woman less than eighteen years of age..$^{23}$

Like Jordan, Syrian law also prohibits marriage on the ground of disparity of age.

is of equal social status and where her guardian, other than her father or grandfather, opposes the marriage without lawful justification. (2) If the opposition is on the part of the father or grandfather the claim of the woman shall not be heard unless she has attained eighteen years of age and the opposition is without lawful reason. Al Alami and Hinchcliffe, Islamic Marriage and Divorce Laws, p. 80.

${ }^{19}$ To quote, art. 12 of the law, "(1) Guardianship is the right of the woman and the guardian shall not contract her marriage unless she authorises him to do so, except in the case of ijbar (compulsion) specified hereafter. (2) A woman shall not make the contract herself but shall authorise her guardian to contract her marriage. (3) A woman shall appoint a male agent whom she authorises to contract the marriage of her ward. (4) It shall be permitted for a guardian, even if he is the father, to compel his daughter who is of age, even if she is a virgin, to marry, except with her permission in which case the judge has the right to compel her to marry in order that she be under the marital authority of a husband of equal status who will take care of her." Al Alami and
Unfortunately it is not stated explicitly what span of years is permitted. ${ }^{24}$

Hinchcliffe, Islamic Marriage and Divorce Laws, p. 200.

${ }^{20}$ As stated in art. 7 of the law, "(1) For a person to have the legal capacity to marry he must be of sound mind and must have attained eighteen years of age. (2) A judge may give permission for the marriage of one of the spouses who is mentally ill if it is established by a medical report that the marriage will not be damaging to society and that it is in his personal interest, provided the other spouse agrees to the marriage explicitly." Al Alami and Hinchcliffe, Islamic Marriage and Divorce Laws, p. 67.

${ }^{21}$ As stated in art. 8 of the law, "If a person who has attained fifteen years of age applies to be married the judge may permit this if his/ her fitness and physical capacity are proved and upon the agreement of his/her legal guardian. If the guardian refuses the judge shall ask him to agree within a period which he shall stipulate and if he does not object or if his objection is not worthy of consideration the judge shall permit the marriage." Al Alami and Hinchcliffe, Islamic Marriage and Divorce Laws, p. 67.

${ }_{22}$ Art. 5 of the law states, "It shall be a requirement for legal capacity for marriage that the betrothed man and woman be of sound mind, that the betrothed man has attained sixteen years of age and the betrothed woman has attained fifteen years of age." Al Alami and Hinchcliffe, Islamic Marriage and Divorce Laws, p. 80; Mahmood, Statutes of Personal Law, p. 130.

${ }^{23}$ As stated in art. 7 of the law stated, "It is forbidden for a contract to be made with a woman who has not attained eighteen years of age if the man is more than twenty years her senior, unless the judge has ascertained her consent and freedom of choice and that her best interests are served by the contract being concluded." Al Alami and Hinchcliffe, Islamic Marriage and Divorce Laws, p. 80; Mahmood, Statutes of Personal Law, p. 130.

${ }^{24}$ As stated in art. 19 of the law, "If the betrothed couple are not of compatible ages 
Morocco puts at eighteen and fifteen years the minimum age of marriage for the man and woman, respectively. People may marry before these ages, but only with the permission of the judge, and the consent of a guardian." 25 Tunisia sets twenty years of age for a man and seventeen for a woman as the minimum age of marriage. ${ }^{26}$

In other words, concern to the marriage guardian, majority of muslim countries does not recognize the compulsion (ijbar) of guardian, even some of them allow a woman who eighteen years of age, to marry herself without the consent of the guardian, or the position of the guardian is replaced by judge. However, a few other countries still recognize the enforcement of marriage guardian to enforce women to marry without agreement of the woman.

Concern to the age of marriage, beside the regulation of minimum age of marriage, it is important to emphasize the regulation of the disparity of age of the spouses, as it is regulated by Jordanian and Syrian.

\section{The Registration of Marriage}

In the case of registration of marriage, in Indonesia as stated earlier, Law No. 22 of 1946 was the first ever to require such documentation. ${ }^{27}$ Art. 4 of this law states, "Unregistered marriage is considered a violation." This violation is punished by a fine of Rp. $50 .{ }^{28}$

The purpose behind registration can be found clearly explained in the preface to art. 1 (1) of Law No. 22 of 1946, and art. 5 (1) of the Compilation, that is, to ensure legal validity, and for administrative purposes, such as in recording the number of births, and deaths among the population.

In the Law of Marriage No.1 of 1974, the compulsory registration of marriage is stated in art. 2 (2), "Every marriage recorded cited in accordance with valid regulation." In art. 2 (1) it is stated, "marriage is lawful if it is done in accordance with the belief of the spouses." In the explanatory section furthermore it is stated, "(i) marriage has to run

and there is no advantage in the marriage the judge may withhold his consent to it." Al Alami and Hinchcliffe, Islamic Marriage and Divorce Laws, p. 218.; Mahmood, Statutes of Personal Law, p.168.

${ }_{25}$ To quote art. 8 and 9 of the law, "Legal capacity for marriage for a boy is attained on completion of eighteen years but if immorality is feared (before this) the matter may be brought before a judge (to give permission for marriage earlier); for a girl legal capacity is attained on completion of fifteen years of age. Marriage before the legal age of discernment is dependent upon the consent of the guardian. If he refuses to give his consent and the parties persist in their wish to marry the matter shall be brought before the judge." Al Alami and Hinchcliffe, Islamic Marriage and Divorce Laws, p. 199.

${ }^{26}$ This is stated in art. 5 of the law, "Both spouses must be free from lawful impediments, moreover any man who has not reached twenty years of age and any woman who has not reached seventeen years of age shall not be allowed to make a contract of marriage. The making of a contract of marriage for a person below the specified age shall depend upon special permission from the courts and this permission shall only be given for pressing reasons and for the obvious benefit of both spouses." Al Alami and Hinchcliffe, Islamic Marriage and Divorce Laws, p. 240; Mahmood, Statutes of Personal Law, p. 173.

${ }^{27}$ Article 1 (1) states, "Muslim marriage, called nikah, is controlled by a registrar of nikah who is appointed by the Religious Affairs or other officers who are also appointed by the ministry of Religious Affairs. Divorce and reconciliation by Muslims are also acknowledged to the registrar."

${ }^{28}$ To quote, art. 3 (1) of the Law, "who performs marriage outside of the provisions of art. 2 (1) or officials is punished by a maximum fine of Rp. 50 ." 
accordance to religious law, and (ii) the religious law is included valid regulation." Therefore, it can be concluded that the registration of marriage is not intended to validate the marriage, but rather to fulfill the administrative requirements. Yet some people view the registration of marriage as compulsory for the validity of the marriage since this is stated in the explanatory section.

In addition, Regulation No. 9 of 1975 , art. 2 (1) states, "Registration of marriage in accordance with islamic teachings, is conducted by the 'officers of registration, as stated in the Law No. 32 of 1954". Thus, the one who conducts registration is an officer appointed by the government through the ministry of Religious Affairs.

The procedure of registration is laid down as follows: first of all there is a public acknowledgement by the officer of marriage; ${ }^{29}$ second, a marriage contract is presented to the officers of registration; ${ }^{30}$ this is followed by its being signed by (i) two witnesses, (ii) the officer and (iii) the wife's guardian ${ }^{31}$ It is stated in art. 11 (3) of PP No. 9 of 1975, "By signing the marriage contract it is proven that the marriage contract has been recorded formally".

However, according to the classical concept, a registration does not have any effect on the legitimacy of marriage, while in the contemporary, as it is proved above, it really does and that an unregistered marriage is considered to be invalid.

To compare, Iraqi law provides for sanctions against private solemnization of marriage, including a maximum fine of thousand dinars or three years imprisonment. ${ }^{32}$

In addition, if there is no lawful or legal proof of a marriage, the affirmation of both spouses is needed to confirm it. Thus, if one of them has already died the marriage contract shall not be provable. ${ }^{33}$
In Jordanian law, the registration of marriage and divorce is likewise compulsory. Marriages not registered can be punished by a fine for a maximum of one hundred dinars. ${ }^{34}$

In Tunisian law, a marriage shall oniy be proved by an official document. But the

${ }^{29}$ Government Regulation No. 9 of 1975 art. 2 (3)

${ }^{30}$ Government Regulation No. 9 of 1975 art. $10(3)$.

${ }^{31}$ Government Regulation No. 9 of 1975 art. 11 (1).

${ }^{32}$ Art. 10 of the law states, "The contract of marriage shall be registered at the appropriate court without fees in a special register in accordance with the following conditions: 1,2 , $3,4,5 \ldots .$. " Art. 10 (5) states, "Any man who contracts a marriage outside the court shall be punished by imprisonment for a period of not less than six months and not exceeding one year, or by a fine of not less than three hundred dinars and not more than one thousand dinars. The penalty shall be imprisonment for a period of not less than three years and not exceeding five years if he contracts a further marriage outside the court whilst already married." Al Alami and Hinchcliffe, Islamic Marriage and Divorce Laws, p. 68-69.; Mahmood, Statutes of Personal Law, p. 118.

${ }^{33}$ To quote art. 11 of the law, "(1) If a man affirm to a woman that she is his wife and there is no lawful or legal impediment to this and if she confirms this then her marriage to hem shall be proved by his affirmation." "(2) If a woman affirms that she has married a man and he confirms this during her lifetime and there is no legal or lawtul impediment the marriage between them shall be proved. If he confirms it after her death the marriage shall not be proved." Al Alami and Hinchcliffe, Islamic Marriage and Divorce Laws, p. 69.

${ }^{34}$ As stated in art. 17 of the law, "(a) The betrothed man must apply to the judge or his deputy for the contract to be performed. (b) The marriage contract shall be performed by a marriage official responsible to the judge on the bases of an official document. The judge 
law still accepts a contract made outside the court. ${ }^{35}$

Therefore, generally speaking the Islamic Family Laws recognize the importance of the registration of marriage. Yet, the function of the registration is still different one from the other. Majority puts the registration to fulfill the administrative requirements, a few puts a requirement of validation of the marriage.

\section{Divorce}

In the area of divorce, Indonesian regulations stipulate that the wife and husband each has the right to propose a divorce but not to legitimate one. The husband's right in this area is called cerai talaq, whereas for the wife it is called gugat cerai. The divorce can only take place in the Islamic court, never outside of it. ${ }^{36}$ In addition, Indonesian regulations do not admit a triple talag. $^{37}$ Thus, there are effectively only two talaqs in Indonesia. Furthermore, a wife has two other possibilities to initiated divorce; (1) khulu' and stipulation (ta'liq talaq).

The grounds for divorce are: (1) adultery or drug-taking or gambling of an irrecoverable nature; (2) disappearance for two years; (3) imprisonment for at least 5 years; (4) harshness and ill-treatment; (5) impotence or other factors leading to impossibility of intercourse; (6) disharmony and continuous dispute; (7) a violation of a stipulation (talliq talaq); and (8) apostasy. ${ }^{38}$ For civil servants and similar functionaries, physical handicap and the inability of a wife to carry

may by virtue of his position undertake this himself in exceptional circumstances and with the permission of the Chief justice. (c) If the marriage is concluded without an official document then the person making the contract, the spouses and the witnesses shall all be subject to the penalty specified in the Jordanian out her conjugal duties, cannot be reasons for divorce. ${ }^{39}$ The implication of this same

Penal Code and to a fine not exceeding one hundred dinars with regard to each of them. (d)... and (e) ...." Al Alami and Hinchcliffe, Islamic Marriage and Divorce Laws, p. 82-83.; Mahmood, Statutes of Personal Law, p. 131.

${ }^{35}$ To quote art. 4, "A marriage shall only be proved by an official document prescribed by law. Marriage contract outside the Court shall be proved by the methods employed in the laws of the country in which the marriage is contracted." Al Alami and Hinchcliffe, Islamic Marriage and Divorce Laws, p. 240.

${ }^{36}$ To quote Compilation, art. 115, "Divorce can only happen in the Islamic court if the Islamic court is not successful in reconciling the spouses.

${ }^{37}$ To quote the Compilation, art. 118-120. Art. 118 states, "talaq raji is the first and the second talaq, in which a husband still has the right to reconcile with his wife during the iddah period." Art. 119 (1) states, "talaq bain sughra is a talaq in which a husband has no right to reconcile, but is able to make a new marriage contract even though it is still during the iddah period." Art. 119 (2) states, "the (instance of) talaq bain sughra are as follows: (a) talaq before intercourse, (b) talaq with payment (khul $($ ), and (c) talaq decided by the Islamic court." Art. 120 states, "talaq bain kubra is the third talaq. This kind of talaq does not admit of reconciliation or a new marriage contract, except if a wife is married to another man, and is subsequently divorced."

${ }^{38}$ To quote The Govemment Regulation No. 9 of 1975 art. 19, and The Compilation arts. 116 and 51, "Divorce can be obtained on these grounds: (1) adultery, or drunk/drugged behaviour, or gambling and so forth which cannot be reversed, (2) disappearance for two years without permission or without legal reason, (3) imprisonment at least for 5 years, (4) harshness or ill treatment, (5) impotence or other factors making intercourse impossible, (6) disharmony and continuous dispute, (7) a violation of a stipulation (ta liq talaq), and (8) apostasy."

39 As stated in Regulation No. 10 of 1983 art. 7 (2), "Divorce on the grounds of physical 
article is that the civil servant needs permission from his or her supervisor before seeking a divorce.

The procedure of divorce within cerai talaq, gugat cerai, khulu' and talig talaq are in principle all similar. First of all, a husband or a wife proposes his desire to obtain a divorce to the Islamic court citing the grounds..$^{40}$ Secondly, an investigation is pursued by the Islamic court into the case..$^{41}$ Finally, a decision is issued by the Islamic court. $^{42}$ ln addition, the divorce dates only from the date of the decision of the court. 43 It is important to emphasize that the approach to the Islamic court is a proposal to proceed with a divorce, not to legitimize a divorce.

Even though stipulation (ta'liq talaq) is defined as an automatic divorce on certain grounds, it does not mean that if a husband violates them divorce automatically happens. The divorce will only take place if a wife decides to pursue it. ${ }^{44}$

To compare, Mahmood points out that in the Tunisian law of 1956 and in Indonesia, a talaq can be effected by a husband only with the prior permission or through the intervention of the court, which must first try to effect a reconciliation, directly or through arbitrators. In the laws of Iraq, Jordan (1976), and Syria (1953), on the other hand, a husband who wants to divorce his wife is advised but not compelled to approach the court. In the Lebanon Law of 1917, the court had to be notified by the husband of his pronouncement of divorce. 45 On the other hand, Jamal J. Nasir, explains that divorce can only be effected by the courts in Tunisia, Syria and Druze Lebanon, and by the order of the judge. In some other countries, e.g., Iraq and Algeria, divorce by a husband takes effect from the time it is recorded by the court of jurisdiction of the locality, if not before the judge. ${ }^{46}$ In addition, according to White, in
Tunisia, Iraq, and the former south Yemen, all pronouncements of divorce have to be made in coust only. ${ }^{47}$

To quote Tunisia's law of 1956, art. 30, "Divorce shall only take place in court."

The law affecting the Druze in Lebanon, art. 42 states, "The spouses may dissolve their marriage by mutual agreement and this dissolution shall take place by being announced in the presence of two witnesses before the judge who shall issue a judgement thereon. ${ }^{49}$

In Syria's law of 1953, art. 88 (3) it is stated, "If this attempt (the dispute problem) is unsuccessful the judge shall give permission for registration of the divorce or mukhala'a and the divorce shall be deemed effective from the date of its occurrence. ${ }^{\text {"50 }}$

Art. $109-110$ of the Law of the Rights of the Family of 16 July 1962 of Lebanon states, "Talaq shall occur by explicit expressions

handicap and the inability of a wife to carry out her conjugal duties, is not permitted."

${ }^{40}$ Regulation No. 9 of 1975 , art. 14, Law No. 7 of 1989, art. 66 (1 \& 2), 67 (b), and the Compilation, art. 129.

${ }^{41}$ Law No. 7 of 1989, art. 68 (1).

42 Law No 1 of 1974, art. 39 (2), Regulation No. 9 of 1975, art. 16, Law No. 7 of 1989 , art. 70 (1), and the Compilation, art. 131 (2).

${ }^{43}$ Regulation No. 9 of 1975, art. 34 (2), Law No. 7 of 1989, art. 81 (2), and Compilation, art. 146 (2).

${ }^{44}$ Compilation, art. 46 (2).

${ }^{45}$ Mahmood, Personal Law, p. 255-256

46 Jamal J. Nasir, The Islamic Law of Personal Status (London: Graham \& Trotman, 1990), p. 125.

${ }_{47}$ White, "Legal Reform as an Indicator of Women's Status", p. 44.

${ }^{48}$ Al Alami and Hinchcliffe, Islamic Marriage and Divorce Laws, p. 245.

49 Ibid., p. 178.

so Ibid., p. 230. 
and by literary expressions which are acknowiedged by the court to be explicit. In the case of those which are not acknowledged as explicit, the occurrence of talaq shall depend on the intention of the husband and if the two parties dispute as to whether or not the husband intended talaq the word of the husband shall be taken upon his oath." "A husband who divorces his wife by talaq shall be obliged to inform the judge of having done so." 51

Art. 39 of the Iraqi law of 1959 states, 4(1) A person who wishes to divorce (by talaq) shall bring a claim before the Shari'a Court requesting this in order to obtain a judgment to this effect. If it is impossible for him to make an application to the court he must register the talaq with the court within the waiting period. (2) The marriage document shall remain valid until it is cancelled by the court." 52

Furthermore, art. 101 of the Jordanian law of 1976 states, "The husband must register his talaq before the judge and if he divorces his wife (by talaq) outside the court and does not register it he shall be obliged to apply to the Shari'a court to register the talaq within fifteen days. Any person failing to comply with this provision shall be subject to the penalty specified in the Jordanian Penal Code. The court shall be required to notify the wife of a talaq in her absence within one week of its registration." ${ }^{153}$

Therefore, it can be concluded that Tunisia and indonesia are the only countries in which the divorce must take place through or with the permission of the Islamic court. The necessity of the court's role in cases of divorce in Tunisian legislation, is based on the role of the arbitrator as stated in the Qur'an itself. ${ }^{54}$

In addition, Tunisia permits women to seek divorce without proving any grounds, provided they are prepared to pay financial compensation to their husbands. ${ }^{55}$ ln Syrian Law, on the other hand, a husband who divorces his wife without a certain ground has to pay compensation for a year's maintenance. The same law is applied in Tunisia. ${ }^{56}$

Stipulation (taliq talaq) in contemporary Islamic family law applies not only in cases of polygamy, but also, for instance, guarantees a women's freedom of movement, and the right to work outside the home. This idea is supported by the Hanbali school of law, in which bases this on the Qur'anic injunction "O you who believe, abide by your contract." The reason why other schools oppose this idea is, that it is not allowed to make a contract in marriage by parties, the only religious (sharifa) has the right. ${ }^{57}$ Put differently, the idea of stipulation has developed in accordance with the development and demands of modern society.

Jordanian law as well has adopted the new concept of stipulation, j.e., that the stipulation of one wife is valid and if the husband violates the stipulation the wife has a right to seek a judicial dissolution. Article 19 (1) is self-explanatory: "If a stipulation is made in the marriage contract for the benefit of either party, it must be complied with, e.g. a stipulation that the wife should have

51 Ibid., p. 163.

52 lbid., p. 74-75.

53 lbid., p. 100-101.

${ }^{54}$ White, "Legal Reform as an Indicator of

Women's Status", p. 59. See al-Nisa' (4):35.

${ }^{55}$ Coulson and Hinchsliffe, "Women and Law Reform", Lois Beck and Nikki Keddie, Women in the Muslim World, p. 41.

${ }^{56}$ White, "Legal Reform as an Indicator of Women's Status", p. 43.

${ }^{57}$ Coulson and Hinchsliffe, "Women and Law Reform", p. 40-41. 
the power to divorce herself in specified circumstances or should live in a specified place or that the husband should not have a co-wife." But such a stipulation can be enforced only if it is incorporated in the registered marriage-deed and also in the certificate issued by the gadi. Violation of such a stipulation shall give to the wife a right to seek dissolution of marriage." ${ }^{58}$ Therefore, there is an important correlation among the restrictions on polygamy, divorce (particularly with respect to stipulation in marriage [tallig talaq]) and registration of the marriage contract.

In the case of Pakistan, the Dissolution of Muslim Marriage Act 1939, as promulgated in 1961, indicates that a husband who insists on polygamy can be a ground for divorce (stated in section 2 of the 1939 Act). Section 2(ii-a), provides that a woman married under Muslim law shall be entitled to obtain a decree for dissolution of her marriage on the ground: "(ii-a) that the husband has taken an additional wife in contravention of the provisions of the Muslim Family Laws Ordinance, 1961."59 In addition, being given the right to divorce is oniy meaningful if the woman actually wants to take up that offer, and she may have many reasons not to do so.60

Furthermore, India's Muslim Personal Law allows for a stipulation to be inserted in the marriage contract that a husband shall not take a second wife. ${ }^{61}$

Egypt is Muslim country makes taking a second wife a ground for divorce, if the first wife initially withheld consent for the husband's second marriage. ${ }^{62}$

Tunisia, Iraq, Iran and former south Yemen, all pronouncements of divorce he made in the court law only.63 Furthermore, Tunisia and Algeria are countries permitted women to insist on divorce without proving any ground, provided they are prepared to pay financial compensation to their husbands. ${ }^{.4}$

In contrary, in the classical concept, a divorce can take place whenever a husband wants to. Therefore, divorce becomes an absolute right of the husband only. The wife is able to obtain a divorce, only if the husband allows her to do so. Even according to some jurists, the talaq from a husband who drunk or under duress, are binding. ${ }^{65}$ Two forms of divorce; (1) repudiation and (2) talaq. $^{66}$ A women permit to divorce on the grounds; disappearance, imprisonment, impotence, failure of husband to maintain the wife financially. ${ }^{67}$ In addition, it is cited that Maliki school is the most liberal idea regarding women's right to obtain a judicial decree of divorce. ${ }^{68}$

To put in different words, the aim of the abolition of one sided right of repudiation (talaq), the extended of the concept of stipulation (talliq talaq), and the judge in court is the only have authority to decide the divorce, is to increase the status of women, and at the same time to guarantee their rights.

s8 David Pearl, dan Werner Menski, Muslim Family Law, edisi ke-3. (London: Sweet \& Maxwell, 1998), p. 244 (8-22).

${ }^{59}$ lbid., p. 264 (8-69).

${ }^{60}$ Ibid., p. 264 (8-70).

${ }^{61}$ Ibid., p. 248 [8-34]).

62 Eric Muller, "Revitalizing Old Ideas", in Lois Beck and Keddi, Women and Law Reform, p. 227.

63 White, "Legal Reform as an Indicator of Women's Status", p. 44.

${ }^{64}$ Coulson and Hinchsliffe, "Women and Law Reform", p. 41.

${ }^{65}$ White, "Legal Reform as an Indicator of Women's Status", p. 42.

$66 \mathrm{lbid}$.

${ }^{67}$ Ibid., p. 56.

${ }^{68}$ Coulson and Hinchsliffe, "Women and Law Reform", p. 41. 
Women's Rights In The Islamic Family Law Of Indonesia; Khoiruddin Nasution

\section{Conclusion}

Based on above description, it is safe to conclude therefore that the status of women in Indonesian Islamic Family Law is increased and their rights are more guarantee compare to the classical concept. Similar picture is found in the majority of other Islamic Family Laws. However, it is still found similar picture with in the classical one, even though the number is small.

The abolition of the compulsion (ijbar) of the marriage guardian by majority of muslim countries purposes to increase the status of women and to guarantee their rights. Similarly, the regulation of minimum age of marriage and of the disparity of age of the spouses is also for similar purpose.

Similarly, the requirement of the registration of marriage is at least become a media to make sure if all requirements of the marriage have been fulfilled and the rights of women have been surely guaranteed.

Furthermore, the aim of the abolition of one sided right of repudiation (talaq), the extended of the concept of stipulation (taliq talaq), and the judge in court is the only have authority to decide the divorce, is also to increase the status of women, and at the same time to guarantee their rights.

\section{Reference}

Afkhami, Mahnaz and Erika Friedl, 1997, Muslim Women and the Politics of Participation: Implementing the Beijing Platform. Syracuse: Syracuse University Press.

Anderson, J. N. D., "Recent Developments in Shari" a Law", The Muslim World, 41 (1951), pp. 113-126, 186-198 and 271-288;
Anderson, J. N. D., "The Problem of Divorce in the Shari" a Law of Islam: Measures of Reform in Modern Egypt", Royal Central Asian Society, No. 37 (1950), pp. 169-185;

Anderson, J. N. D., Hukum Islam di Dunia Moderen, 1990, terj. Machnun Husein. Surabaya: Amarpress.

Anderson, Norman,1976, Law Reform in the Muslim World. London: The Athlone Press.

Beck, Lois and Nikki Keddie,1978. Women in the Muslim World. Cambridge, Massachusetts: Harvard University Press.

El Alami, Dawoud dan Doreen Hinchcliffe,1996. Islamic Marriage and Divorce Laws of the Arab World. London, the Hague, Boston: Kluwer Law International.

Esposito, John L., 1982, Women in Muslim Family Law. Syracuse: Syracuse University Press.

Faridi, R. and M. Siddiqi, (eds.), 1973,Muslim Personal Law. Delhi: Markazi Maktaba Islami.

Fazlur Rahman, "A Survey of Modernization of Muslim Family Law", International Journal of Middle East Studies, 11 (1980).

Katz, June S. \& Ronald S. Katz, "Legislating Social Change in a Developing Country: The New Indonesian Marriage Law Revised", The American Journal of Comparative Law, vol. 26, 1978. 
Topik: Bencana Alam dan Kemanusiaan

Mahmood, Tahir, 1987. Personal Law in /slamic Countries. New Delhi: Times Press.

Mahmood, Tahir, Statutes of Personal Law in Islamic Countries: History, Texts and Analysis, Revised Edition. Delhi: ALR, 1995.

Nasir, Jamal J., The Islamic Law of Personal Status, 1990. London: Graham \& Trotman.
Pearl, David, dan Wemer Menski, 1998. Muslim Family Law, edisi ke-3.London: Sweet \& Maxwell.

Stuers, Cora vreede-de, 1960 . The Indonesian Woman: Struggle and Achievements. Netherlands: Mouton \& Co., Printers.

\section{$\square \square \square$}

